\title{
ГЕНДЕРНЫЕ И ДЕМОГРАФИЧЕСКИЕ ФАКТОРЫ В УКЛАДЕ ХОЗЯЙСТВА МУСУЛЬМАН СИБИРИ
}

Анализируются гендерные и демографические фракторы, повлиявшие на социальное поведение мусульман Сибири в течении нескольких столетий. Это важно для понимания условий трансформации сознания и поведения этой части регионального социума.

Ключевые слова: Сибирь, мусульмане, демография и экономическая культура, гендер и история повседневности.

\section{A.P. YARKOV}

\section{GENDER AND DEMOGRAPHIC FACTORS IN THE WAY FARMING MUSLIMS OF SIBERIA}

Examines gender and demographic factors affecting the social behavior of Muslims in Siberia for several centuries. This is important for understanding the conditions of transformation of consciousness and behavior of that part of the regional society.

Keywords: Siberia, Muslims, demography and economic culture, gender and history of everyday life.

Используемые в статье понятия традиционный ислам (т.е. традиционное для многих мусульман Сибири понимание ислама ${ }^{1}$ ) и ваххабизм вошли в оборот у современных верующих, хотя не всегда его верно классифицируя, тем самым еще более (нежели в административном плане) раскалывая умму. Отсутствие диалога - одна из причин ее затяжного кризиса.

Между тем как основополагающий признак современного культурного пространства - именно диалог (через людей) светского государства и религиозных объединений. В том диалоге велика роль социальных (гендерных и демограсрических) фракторов в особенностях хозяйственно-экономического уклада семьи, где, например, статус сибирячки всегда был намного выше, чем у единоверок Средней Азии и Поволжья. Это и местные культы «мучениц за исламскую веру», и правила поведения в сфрере разделения труда, в вопросах взаимоотношений в социуме [10, с. 74-75]. Так, например, о месте некоторых мусульманок в ином по

1 «Грозненская фетва» (принятая в феврале 2016 г. в Грозном на конференции богословов - улемов) требует следования мутаридской или ашаритской акаде и одному из четырех мазхабов: ханафитскому, маликитскому, ханбалитскому, шафиитскому). 
характеру городском экономическом и коммуникативном пространстве свидетельствует то, что в 1657 г. среди тюменских купцов упоминалась К. Шукурова - вдова «приезжего Бухарина Баянды Ширипова».

В зависимости от времени и социальных особенностей статус изменялся, но разграничения мужской и женской ролей в обществе и семье сохранялось [2, с. 44-45]. Заметим, что многоженство здесь не являлось распространенным явлением (в местах проживания ссыльнопоселенцев-мусульман диспропорция по полу была значительна), а количество детей не регламентировалось, но велика была младенческая смертность (например, в Вернеудинске в 1912 г. на 1000 смертей детей до 3 лет коэффиццент 53,7, тогда как средний по городу - 40,2). Средняя продолжительность жизни мусульман (по этому городу) была мала (лишь 2,8 \% дожили до 61 года), уступая в этом отношении православным землякам и мусульманам Западной Сибири, издавна жившим в привычном для них климате [7, с. 77-78].

Со временем, исходя из российского законодательства, мусульмане встраивались в систему общепринятого социального поведения и даже судопроизводства: мулла М. Машкин в 1792 г. засвидетельствовал перед общинным сходом юрт Карбанских (Кысылбаш) о побоях замужней женщины; в 1800 г. старшина Тюменского округа М. Кучаков доносил земскому комиссару, что разбирательство о «...бесчеловечном битие Калиметом Кучуковым своей жены проведено им, старшиной, "обще с муллой агуном Сеитом Муллагуловым с приглашением старших лутчих людей"»[4].

В условиях города мусульмане, в особенности служилые татары и бухарцы, проживая в особых слободках, вынуждены были ограничить количество «городских» жен и соблюдать некоторые правила поведения и нормы, соответствующие общепринятым в государстве и местном социуме, если стремились укрепить свое экономическое положение, занять статусное положение.

Принятие православия девушками из мусульманской среды влекло за собой их выдачу замуж за новокрещеного или русского, но не всегда меняя гендерные отношения 1 . В иных случаях за мусульманками признавалось право на суждение и повышенный экономический «вес» и, соответственно, социальный статус. Сибирячки были вхожи в мечеть и, более того, социально активнее, чем их единоверки в других регионах. Примечательна помощь в перестройке ветхой деревянной мечети (1820-х гг.) в юртах Казаровских (Кырынкуль), оказанная в 1884 г. бухаркой Б. Абсалямовой. За собственный счет, не полагаясь на средства бедного прихода и помощь казны, она построила новую - на каменном фундаменте.

\footnotetext{
${ }^{1}$ Количество детей у крещеных и во второй половине XX в. на порядок больше.
} 
Традиции исполнения обрядов и предписаний соблюдались, в основном, свободными гражданами, у которых имелись экономические возможности. Так, на собранные иркутским купцом Хисаметдин-бабаем в качестве закята средства позволили нуждающемуся в поддержке уроженцу Западной Сибири А.Г. Ибрагимову совершить обязательный для мусульман хадж.

Затворничество не характерно для местных татарок (а с течением времени и бухарок), но гендерные права и «роли» выстраивались «по традиции». И лишь немногим суждено их изменить. Трансформации заметны среди внешних примет при анализе глубинных процессов, проистекавших в среде купечества и интеллигенции, своим положением, возможностями и предназначением призванных внедрять инновационные модели, стратегии, технологии. Охватил это процесс и часть образованных татарок и бухарок (следует понимать образование лишь на уровне начального, так как в 1897 г. в Тобольской губернии лишь одна тоболячка и, заметим, старше 50 лет, имела подготовку на порядок выше) в зажиточных семьях. Ими, например, стал культивироваться самодостаточный образ Сузге - одной из жен хана Кучума. С этой целью поэма П.П. Ершова «Сузге» в 1889 г. была театрализована местной интеллигенцией на «Сибирских вечерах», а в ее постановке принимали участие мужчины и женщины из татар и бухарцев [14, с. 11].

Материалы 1897 г. свидетельствуют, что в структуре полов среди мусульман (по записанному исповеданию) из 6981 чел. в Иркутской губернии 4423 - мужчины (где 4129 - приезжие). Среди них были люди привелигированого социального статуса (в Иркутском военном округе квартермейстером служил генерал-майор М.С. Сулькевич, литовский татарин по происхождению), образования и имущественного положения (купец І-гильдии Ш. Шафигуллин 1 ), чья религиозная принадлежность принималась во внимание, но не была определяющая по их роли в обществе.

Как и в других восточных регионах отмеченное доминирование мужчин - отражение ссыльного и воинского контингента. В ряде случаев это облегчало повторное замужество «иноверок», в иных регионах России (Кавказ, Поволжье, Средняя Азия) затрудненное и морально осуждаемое.

На показатели естественного прироста среди мусульман влияла не только детская смертность из-за слабости (или отсутствия) медицинского обслуживания, но и соотношение поколений. Показательно, например, среди татар Тобольской и Томской губерниях, казахов в Ак-

${ }^{1}$ Впрочем, эта личность оценивается в истории общины неоднозначно. С одной стороны, известна его политическая активность - являлся членом партии кадетов. Но еще в 1912 г. он стал одним из инициаторов создания подпольного татаро-турецкого комитета, который позже оказал содействие побегу находившегося на положении военнопленного турецкого генерала Исхан-паши Редвана. 
молинской области - 6-7 \% (на 100 женщин) по данным 1909-1910 гг. уступала приросту населения недавних переселенцев (преимущественно молодых).

Несмотря на усилия джадидов, отношение к образованию долго оставалось консервативным. Например, в женских мектебе Томска обучение было платное, тогда как мужские получали пособия от богатых мусульман. К тому же, не получив утверждения учебным начальством, в 1909 г. мектебе для девочек закрыты. Обучались мусульмане и в светских учебных заведениях. Это, в частности, позволило иркутскому крестьянину Г.Ш. Неометулову поступить в технологический институт в Томске, а затем получить военное образование, и в итоге стать министром Временного правительства автономной Сибири.

На сомнения в правомерности выданных томским ахундом X.A. Хaмитовом документов на преподавание мусульманкам ахунд ответил: «и по настоящую пору в Российской империи нет такого учреждения, которое бы подготавливало учительниц для детей женского пола, так как по исламу воспрещается мужчинам после десятилетнего возраста девочки видеть лицо - за исключением своих родных детей и близких родственников» [13, с. 232]. Поэтому он вынужден, как многие муллы и ахунды, выдавать удостоверения оказавшимся в отчаянном положении из-за несовершенства законодательства.

Ожесточенные споры на муссъездах 1917 г. вызвал вопрос о месте женщины в умме [11]. Одни отражали модернизационные процессы, а их противники считали, что положение обязано сохраниться, осуждая браки мусульманок с офицерами и солдатами квартировавших в тюркских селениях частей Белой и Красной Армий. Истина оказалась посредине: причина сокращения числа обучавшихся в 1918-1920 гг. девушек в томском медресе «Дарульмугаллимат» (с 18 до 0) объяснялась не только сложностью переживаемого времени, но и «характером мусульманского населения, веками обижаемого и обделяемого в деле просвещения» [5, с. 43-44].

С 1921 г. в Азиатской части страны (но лишь в освобожденной Красной Армией, поскольку Гражданская война закончилась в Западной Сибири поздней осенью 1919 г. (и только весной 1923 г. - на Дальнем Востоке) стали проводится конференции мусульманок с целью приобщения их к общественному (социально одобряемому) труду и антирелигиозной пропаганде. Между тем, оставшиеся с «микулаевских времен» браки с двумя женщинами сохранялись и среди коммунистов. Так, у председателя сельсовета и единственного коммуниста в юртах Вершинских Айтбаева в 1923 г. было две жены. На вопрос партийной комиссии он ответил честно вопросом: «А куда их деть?» [8, с. 17].

Об изменении соотношения гражданского права и шариата говорит описанная в 1924 г. ситуация в Кузбассе, когда не к мулле, а к чиновнику 
пришли две мусульманки с заявлением о разделе имущества. На вопрос: «почему не обращаются за разрешением этого вопроса к Корану, к мулле?», последовал ответ: «есть суд, поэтому мулла не может судить». Примечательно, что дело происходило в среде переселенцев из Поволжья, за семь лет до революции переехавших в Сибирь, успевших, однако, на новом месте поставить мечеть и мектебе, т.е. «изначально религиозных» [6, с. 3].

В «татарских» школах, мусульманских детских домах и детсадах стали работать женщины (Р. Мухитова, Ф. Ахметова, Н. Дашкова, Н.Р. Мукансова-Юняева и других), а в 1924/1925 учебном году в Томске уже почти половина учеников - девочки [3]. Так, постепенно, изменялись социальные роли и род профессиональной деятельности, а статус женщин повышался.

Поскольку ЗАГСы отказывались регистрировать многоженство, то в некоторых семьях эта система устраивалась «по договоренности». Впоследствии эмансипация затронула горожанок и живших в смешанных селениях, а советизация, индустриализация и коллективизация привели к интенсивному размыванию прежнего неравенства в образовании, профессиональных занятиях, социальном поведении и в сельском социуме. В то же время в силу сложившихся обстоятельств на женщин выпала миссия хранителей традиций.

Потребность в духовном окормлении изменила представление о роли мусульманки, а внешний и внутренний уровень личной конфессиональной идентификации зависел от иных факторов [13, с. 231]. Например, к 1930-м гг. в районе Иркутска находилось около 30 тыс. татар, хотя не все из них уже были религиозны. А вот сосланный богослов, трижды совершивший хадж С. Шагидуллин демонстративно был направлен чернорабочим на золотодобычу. Семья в 1932 г. обреченно последовала за ним.

В 1934 г. выехавшие из Казахской АССР на производственные предприятия Иркутска 120 казахов изменили род профессиональных занятий. И хотя их религиозные практики в тот период не изучены, предполагаются, что они - традиционны, поскольку все приехали из сельской местности (где исламские нормы прочнее).

Относительно легче ситуация с соблюдением религиозных предписаний и гендерного поведения складывалась у тех, кто в 1940 г. из Европейской части РСФСР организовано (по вербовке) переехал в Сибирь. Например, в Иркутскую область было направлено из Поволжья 1,9 тыс. семей (8,4 тыс. чел.) для развития сельского хозяйства. Мусульманам при компактном переселении и при традиционном сельском укладе хозяйства удавалось сохранить (воспроизвести) многие «линии социального поведения», активно «размываемые» советскими установками в местах исхода. Касалось это в равной степени гендерных и демографических аспектов. 
Сибирь становится также «территорией исправления» осужденных по уголовным и политическим статьям, где присутствовали и безвинные люди. В 1943 г. в ходе «депортации возмездия» в Иркутской области, например, расселили карачаевцев. На 1 января 1953 г. среди местных спецпереселенцев отмечены также 75 ингушей, 128 крымских татар, 152 чеченцев. Они традиционно более религиозны, хотя в местных условиях скованные в соблюдении требований своей веры. Немало депортированных работало в системе АнгарЛАГа и ИркутЛАГа. Только в Тайшетском районе действовали ЮжЛАГ и ТайшетЛАГ, в 1949 г. объединенные в ОзерЛАГ, где, в частности, находился осужденный по ст. 58-10 на 10 лет за активную религиозную деятельность и устройство мечети в Новосибирске Ф.Н. Вахитов.

Плановые переселения вызвали увеличение повсеместно в Сибири числа мусульман (известно, например, что в 1959 г. среди жителей Приангарья $2 \%$ - татары), которые не могли открыто манифестировать вероубеждения, но их придерживались. Не имея печатных Коранов, они использовали рукописные тексты, а ритуалы обеспечивали «сведушие» из пожилых.

Эпоха «застоя» определяла дисбаланс между декларируемыми в СССР и реальными возможностями в регионе для исповедания веры. Это проявлялось на уровне семейной памяти и бытового соблюдения установок. Но оставались «зримые» плоды их присутствия - мусульманские участки городских и сельских кладбищ, а «бродячие» муллы стремились получить какой-либо законный статус.

В зонах промышленного освоения Сибири и позднесоветский период средняя детность в «мусульманских» (по происхождению) семьях лишь немного больше общесоюзных показателей, но сохранялась, для примера, в Восточной Сибири [9, с. 23]. Интересно, что мигрировавшая с семьей в ямальский Надым узбечка Дж. Ходжаниязова работала сварщицей, имея пять детей.

Совместные браки не всегда сопровождались внедрением гендерного разделения в общественном пространстве, в быту и индивидуальном поведении. Хотя внешне оно позиционировано: на страницах тюменской татарской газеты «Янарыш» молодые люди по-разному репрезентированы в учебе, на производстве, общественной и культурной copepe, и по-иному - в «ролях» жениха и невесты «по-исламски» [12].

В современных условиях, в зависимости от удельного веса мусульман (по происхождению), доминирования общегражданских, либеральных или консервативно-охранительных фракторов гендерные аспекты проявляются не только на уровне семьи [1, с. 130]. Показательно, что в новых мечетях, например, в шахтерском (т.е. пролетарском по советскому определению) городе Кисилевске, к основному зданию пристроен женский зал, уступив давлению сторонников отделения в пространстве. 
Между тем, как в социальном поведении только в предопределенных ритуальных ситуациях сибирские и казанские татарки, башкирки, казашки отделялись от мужчин и переходили на «вторые роли» (например, на кладбище или религиозных праздниках). Но такое разделение пространства в целом не поддержано.

Среди мигрантов ситуации более различны. В ряде случаев при коллективных встречах деление по гендерному признаку четко фиксируемо, как, в принципе и в социальном поведении «на улице» и дома.

Так, в семьях «сибиряков-кавказцев» деление на мужскую и женскую виды работ, социального поведения в домашних условиях сохранено, но оно «размывается» при мероприятиях смешанного этно-конфессионального характера.

В целом же можно утверждать: выявленное течение нескольких веков бытования ислама в пространстве Сибири соотношение обычного права, шариата и государственных законов показало возможность их применения и в гендерных вопросах, не нарушая установок ислама, находя разумный компромисс между заповеданным Аллахом и реально сложившимися, в том числе экономическими и социальными нормами, принятыми в светском обществе.

\section{Список использованной литературы и источников}

1. Аксянова Г. А. Этнодемографрия Западной Сибири в конце $\mathrm{XX}$ века / Г. А. Аксянова // Археология, этнографрия и антропология Евразии. - 2011. № 2. - C. 128-142.

2. Ахметова Ш. К. Женщина в исламе / Ш. К. Ахметова // Земля Сибирская, Дальневосточная. - 1992. - № 7-8. - С. 44-45.

3. Биктемирова Т. Татарки-просветительницы / Т. Биктемирова, Н. Хамитбаева // Актуальное национально-культурное обозрение. - 2001. — № 3. - С. 14-17.

4. Валеев Ф. Т. Сибирские татары: культура и быт / Ф. Т. Валеев. - Казань : Татар. кн. изд-во, 1993. - 232 с.

5. Валеева А. Ф. К вопросу о женском образовании в мусульманских школах в Сибири в XIX - нач. XX вв. (до Октябрьской революции) / А. Ф. Валеева // Влияние ислама на культуру народов Сибири : материалы науч.-практ. конф. Тюмень, 1998. - С. 43-44.

6. Гарифуллин И. Б. Сила братской дружбы / И. Б. Гарифуллин // Блокнот агитатора. - 1982. — № 16. - С. 3-4.

7. Зверев В. А. Естественный прирост населения Западной Сибири в конце имперского периода / В. А. Зверев // Азиатская Россия: проблема социальноэкономического, демографического и культурного развития (XVII-XXI вB.) : материалы Междунар. науч. конфр. / отв. ред. В. А. Ламин. - Новосибирск : Параллель, 2017. - С. 77-78.

8. Маннуров Ш. Ф. Агымсуларга карап / Ш. Ф. Маннуров. - Казань : (б.и.), 1974. $-23 \mathrm{c}$.

9. Татары на Байкале: от истории и становления общины к развитию национально-культурной автономии. - Улан-Удэ : Бурят. кн. изд-во, 2017. - 184 с. 
10. Ташкалова В. С. Культура сибирских татар: история и современность / В. С. Ташкалова. - Тюмень : Вектор Бук, 2008. - 212 с.

11. Фаизов С. Движение мусульманок России за права женщин в 1917 г.: страницы истории / С. Фаизов. - Нижний Новгород : Растр НН, 2005. - 104 с.

12. Шишелякина А. Л. Визуальные репрезентации в национальной прессе: опыт «прочтения» фотографрий / А. Л. Шишелякина // Вестник археологии, антропологии и этнографии. - 2011. - Вып. 2 (15). - С. 177-180.

13. Ярков А. П. К вопросу о трансформации гендерных отношений в умме региона / А. П. Ярков // Сулеймановские чтения : материалы и докл. XV Всерос. науч.-практ. конф. - Тюмень, 2012. - С. 230-232.

14. Ярков А. П. П.П. Ершов и «тобольский тип культуры» / А. П. Ярков // П.П. Ершов и культура Тюменского региона : сб. ст. - Тюмень : Изд-во Тюм. гос. ун-та, 2005. - С. 10-13.

\section{Информация об авторе}

Ярков Александр Павлович - доктор исторических наук, ведущий эксперт Экспертного научного центра по противодействию идеологии экстремизма и терроризма, Тюменский государственный университет, 625003 , г. Тюмень, ул. Володарского, 6; e-mail: ayarkov@rambler.ru

\section{Author}

Alexander P. Yarkov - Doctor of History, Leading Researcher of the Expert Scientific Center for Combating the Ideology of Extremism and Terrorism, Tyumen State University, 6 Volodarskogo Str., 625003, Tyumen, Russia; e-mail: ayarkov@rambler.ru 